IJIET, e-ISSN 2548-8430, p-ISSN 2548-8422, Vol. 1, No. 2, July 2017

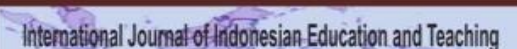

IJIET

International Journal of Indonesian Education and Teaching

http://e-journal.usd.ac.id/index.php/IJIET

Sanata Dharma University, Yogyakarta, Indonesia

\title{
CROSSCUTTING RELIGIOUS EDUCATION FOR A BETTER SELF- UNDERSTANDING AS A RESPONSE TO RELIGIOUS EXTREMISM
}

\author{
Setyawan Andreas \\ Sanata Dharma University \\ asetyawan@usd.ac.id \\ https://doi.org/10.24071/ijiet.2017.010204 \\ received 6 May 2017; revised 18 June 2017; accepted 1 July 2017
}

\begin{abstract}
Interreligious education has been recognized as alternative for mono-religious and multi-religious education in the Western World since 1990's. This model underscores plurality both as a part of departure and as a possible result of religious education and at the same time it avoids a purely objective approach to the multitude of religions. However, there has been hardly any trace of interreligious education in Indonesia and in fact, even some people agree to abolish mono-religious education in the schools, which is considered to be vulnerable to favouritism and communal tensions. This study proposes a certain way of learning called cross-cutting religious education which may be applied within mono-religious model. The main concern is the following research questions: To what extent can crosscutting religious education lead to moderation and how can it provide cognitive, affective, and attitudinal dimensions which are required to restrain the tendency of religious extremism? The author argues that a crosscutting religious education in high schools through religious literature provides a better self-understanding which in the long term reduces the tendency of religious extremism. Thus, the study shows a method of hermeneutics which results in a better self-understanding of certain religious tradition based on the reading of different religious tradition texts.
\end{abstract}

Keywords: interreligious learning, mono-religious model, hermeneutics, religious extremism, cross-cutting

\section{Introduction}

At first glance, most people assume that poverty and ignorance are two overriding answers to the question about what drives someone to become a religious extremist. However, Haroon K. Ullah, a senior State Department advisor and a foreign policy professor at Georgetown University, found something intriguing when he observed how Islamist extremist group spread their influence in Pakistan. The people recruited by this group are well-fed and well-read. Thus, poverty and ignorance have almost nothing to do with what drives people to Islamic extremism. Haroon proposes two answers to explain how people are easily recruited by extremist group: (1) a desire for meaning and for order and (2) a desire for change (Ullah, 2015). 
He describes that "Places like Pakistan are submerged in chaos and corruption. Islamists promise clear cut solutions to every problem: here is how things will change if you follow these rules. And only these rules." Meanwhile, "The old corrupt order... must be overthrown, and that can only happen through violent action. Again, it is Islamists that step in, with a promise to create a new form of government. Then throw in a strong sense of victimhood - we are not responsible for the sorry state of our country; others have brought us down - and you have a toxic brew that many willingly imbibe. These, of course, are the same easy answers that tyrants and demagogues - from Lenin to Mussolini to Hitler to bin Laden - have always offered their followers" (Ullah, 2015).

The desire for meaning and change is, in fact, a matter of religious dimension which nowadays is closely related with pop-culture and one acknowledges that "beyond the symbolic content of the advertising spectacle, a significant part in aggrandizing the culture force of advertising is attributed to the way in which it succeeds to contain religious dimensions in its mechanisms, such as sacramentality, divine mediator, ultimate concern, and the passion for the impossible" (Grad, 2014). Thus, religious values play an important role in the production of meaning through mass media.

Since the production of meaning through media culture does not depend on a single religion, conflict of interpretations is unavoidable. This conflict cannot be satisfactorily managed without interreligious dialogue and there is no interreligious dialogue without interreligious encounter (Fisoni, 2005). This interreligious encounter has implications for religious education, regardless its diverse understandings, thus its ambiguities, and approaches (Jackson, 2016), which in turn determines how religious materials will be delivered. It is assumed here that there are three models of religious education: (1) mono-religious education as a method of learning in a certain religious environment, (2) multireligious education as a method of learning about religions, and (3) interreligious education as a method of learning from religions (Ziebertz, 1993) and that the last model is a legitimate critique and alternative for two other models which has been developed since 1990s (Pollefeyt, 2007).

Unfortunately, it is clear that in Indonesia the preferred type of religious education is mono-religious model. This preference was coined by the Education Law No. 2/1989 and the current law, that is No. 20/2003, has strengthened it. This preference for mono-religious education has received some critiques as lacking of the spirit of moderation that is being vulnerable to religious favouritism and communal tensions. Moreover, mono-religious model could lead to ethnocentrism and religiocentrism as well as the risk of strengthening positive in-group attitudes and, at the same time, negative attitudes towards religious out-groups (Yusuf \& Sterkens, 2015).

However, this legal preference for mono-religious model should not be considered as great barrier for dialogue. This study proposes an interreligious learning within mono-religious education which may be called crosscutting religious education. The word 'crosscutting' here is taken from political studies to underline the importance of moderation in plural societies. "According to the theory of crosscutting or overlapping memberships... crosscutting entails cross- 
pressures that make for moderate attitudes and actions" (Lijphart, 1977). The purpose of crosscutting religious education is basically in line with the aim of mono-religious education outlined by the Education Law, namely, "creating a religious community, where a deep, extensive and even critical understanding of religion is nurtured" (Amin, 2013). In spite of it, crosscutting religious education attends "to the particular words, images, and behaviors through which the other represents himself" (Berling, 2004). Thus, crosscutting religious education is theoretically dual-purpose, that is, inculcation of religious values as well as moderation for peaceful co-existence. There are certainly some requirements to attain that dual-purpose.

\section{Theory}

The foundation for crosscutting religious education is precisely the goal idealized by mono-religious model, that is, appropriation of a particular religion (Sterkens, 2001). One who appropriates his or her religion will understand the meaning of his or her religion, live it out, express, or articulate it within his or her life. As a consequence, as said by The Pope John Paul II, "a faith which does not become culture is a faith which has not been fully received, not thoroughly thought through, not fully lived out" (Gallagher, 2003). Therefore, a true faith should be expressed through culture and crosscutting religious education takes expressions of other faith (or religion) as a point of departure, not the sources of faith (scriptures, tradition, magisterium, for instances). The possibility of taking other's sources of faith for a genuine dialogue is neglected here.

There are two reasons for this. Firstly, interreligious dialogue, for which interreligious learning is bound, is best understood as a way to better selfunderstanding, not primarily better understanding of other religions, by departing not from one's own religion, but from other's. Considering Ward's observation on Karl Barth's theological itinerary (Ward, 2005), besides the issue of incommensurability (Ruth, 1997), it is clear that one cannot speak theologically out of experience that is not part of his or her beliefs. Moslems or Jews, for example, cannot speak theologically on the basis of their belief of the risen Christ. Secondly, considering Paul Ricoeur's concepts of distanciation and appropriation in his hermeneutical theory (Ricoeur, 1976), this point of departure serves as a moment of dispossession of the egoistic and narcissistic ego. Methodologically one does not hold his or her own religious heritage, but make a distance from it and taking expression of other's faith becomes a means of distanciation. Here the possibility of shifting perspective from auto-interpretation to allo-interpretation and vice versa (Sterkens, 2001) has its place.

However, there are some conditions for faith's expression as a point of departure: (1) its textual characteristics and (2) its openness to cultural hermeneutics. First, the material object should be something that can be treated as a discourse, which is fulfilling four characteristics as analyzed by Ricoeur. To put it briefly, the medium for crosscutting religious education should be a written discourse, that is, a text. The medium may be also an action provided that the action fulfils textual characteristics (Ricoeur, 1991). 
Second, the text is not necessarily at random. Taking Ward's conception of culture as symbolic world-view into consideration and admitting the dynamic character of cultures (Gallagher, 2003; Ward, 2005), this study suggests the text be other than Scriptures or any kind of treatises on specific teachings in the context of a certain faith. One criterion for distinguishing which text can be included as medium for crosscutting religious education is in regard with the congruency between real reader and implied reader. If the structure of the text does not allow separation between the real reader and the implied reader, then that text cannot be used as medium for crosscutting religious education.

Therefore, crosscutting religious education takes a text whose implied reader belongs to other faith or belief without violating the text. Violation happens if the real reader reads and interprets the text while it is properly read through the eyes of other faith. That is why crosscutting religious education cannot take the textual sources of faith that is Scriptures as a whole. What kind of text, then, can be treated as medium if it has to be an expression of faith but it can be understood through interpretation of other faith?

Strictly speaking, the answer is religious literature that has a narrative structure. One can express his faith through literature and other person who belongs to other faith may interpret it without dropping his own faith. Another question may arise: Is it not another kind of violation, that is, of treating a text subjectively so the reader falls into an arbitrary relativism? To answer this question the author owes Ricoeur's hermeneutical theory to explain the procedure of doing crosscutting religious education, instead of merely relying on common sense.

Hermeneutics in Ricoeur's discourse is a way of self-understanding through a text. Hermeneutics has a character of phenomenological and existential (and critical as well). It is existential to the extent that hermeneutical knowledge functions not only as cognitive process, but also a way of being. Through hermeneutics, one can better understand himself. Whereas the phenomenological dimension of hermeneutics gives a place for intentionality. Here understanding is a reciprocal relationship between subject and object. As a consequence, interpretation is not only determined by internal dynamics of the interpreter, but also by the grammar and syntax of the text.

Practically a text can make sign and symbol more extensive but at the same time this mediation breaks off the intersubjective dialogue between writer and reader. The writer is not present when the text is read and the reader was not present when the text was written. If Schleiermacher pays his attention to the intention of the writer, then Ricoeur distinguishes himself by arguing that the task of hermeneutics cannot simply be defined as an effort to find the intention of the writer, but it must be becoming a route to self-understanding as human being (Simms, 2003).

For the sake of a better self-understanding, considering four constitutive elements of discourse, Ricoeur proposes four hermeneutical categories (Ricoeur, 1991; Haryatmoko, 2016). The first category is distanciation to the object of hermeneutics through its structure. It means that the object of hermeneutics should be fixated on written form. This is a condition for autonomy of the text so that 
distanciation happens: it becomes autonomous to the author's intention, to the cultural and sociological backgrounds, and also to original reader, original addressee, or implied reader (Ricoeur, 1991). The second category is objectivation through the structure of the text. Here is the place for observation to the logic of relationship among elements within the structure of the text. This second category does not allow a notion that text's meaning depends on subjective dynamic of the interpreter because text has its "own world" which may exceed even the author's world. Both categories (distanciation and objectivation) are objective pole of interpretation. This shows that text has an immanent structure which can be understood by way of structural approach but at the same time refers to external entity passing over linguistic and philosophy of language, which is the world of the text. Here it is the trajectory which cannot be accommodated by the intentionality of both writer and reader.

The third category is the world of the text, that is, the main message. It is not a world limited by the intention of the author, but it is a world disclosed based on the constitutive elements of the text. The world of the text becomes a term of reference, an orientation to the readers. In other words, the interpretation of the reader is oriented toward a world constituted by the text. Therefore, the world of the text cannot be intentional prejudices or interests of the reader. The fourth category is self-understanding or appropriation. The world of the text is meaningful insofar it is internalized within the life of the reader, that is, if it is related to concrete situation of the reader or interpreter. This encounter between the world of the text and the world of the reader may be called a fusion of horizons which in turn will change the world of the reader by way of appropriation (Ricoeur, 1976).

The appropriation here is actually a distanciation too, not from the author, but from the reader. The reader must uncover his or her unconscious ideologies which have been instilled by respective religion. This distanciation can be developed through a critique of ideology and deconstruction, besides creative imaginations (Haryatmoko, 2016). The first two models are negative in their forms in the sense that they challenge any ideology or teachings subconsciously held by the reader. In fact, they have a positive role to purify the reader's understanding of his or her beliefs. The same thing applies to creative imaginations, which may open new possibilities in living out the reader's belief, related to the world of the text, through arts performance or experiences. Thus, the third and fourth categories of hermeneutics are subjective pole, which are closer to the internal dynamics of the reader. It is in this subjective pole that the reader has a chance to understand himself better in the sense that his or her horizons are broadened or purified within his or her context of life.

These two poles of hermeneutics will not permit crosscutting religious education to violate the text because the reader has to face objective dimensions of the text. On the other hand, crosscutting religious education provides enough space for the reader to develop his or her personal involvement in the real world connected to the world of the text. 


\section{Theory Application}

Based on this theoretical framework, a crosscutting religious education may be delivered with following steps. Firstly, students take a literature written by a real author who belongs to other faith or belief, assuming two things: (1) it will imply to existence of implied author and implied reader of the same faith or belief with the real author; (2) it contains standpoints of other faith or belief. They read the literature and after finish, they are asked to give their impressions toward the story. Here the students identify their own feelings while they were reading and after they finish reading and their opinions about the literature. Secondly, students do a close reading, observing the literature with the help of narrative analysis procedure, that is, to find fundamental elements of the story (protagonistantagonist, time-place, plot, narrator, reader, point of view, etc.). This step will help the students to get the surface meaning of the story (Powell, 1990).

Following that observation is structural analysis which may help students to go into detail in order to find the grammar of literature. The structural analysis unfolded by Greimas and Barthes may be a great help here. Through careful observation on these narrative and structural analyses students may find the world of the text, which will be term of reference for the next analysis. It can be said here a hypothesis that the world of the text is to be found in the intersection between communication axis (sender-receiver) and desire (or project) axis (subject-object) in actantial model. As a part of this structural analysis students may list values lived by the subject in a form of binary opposition. It will also help students to explain the world of the text and formulate some deep meanings based on the world of the text. The next step is appropriation to the world of the text by way of some methods of distanciation: critique of ideology, deconstruction, and creative imagination.

An example is given here by studying a short story written by Ali Akbar Navis, a Moslem writer, entitled "Robohnya Surau Kami" (The Fall of Our Local Mosque), assuming here the students as its real readers are Catholics. It is a story about Kakek, a caretaker of the surau (a small mosque), who committed a suicide after Ajo Sidi, a very busy man, likened him to fictional character with hajj title named Saleh (means pious). Ajo Sidi told Kakek how God almighty chased Saleh away to hell after his death even though Saleh had observed all God's commandments and dedicated his whole life to worship God. He was late to realize that God wanted his people to live in fellowship. Logically, Saleh's struggle for entering heaven became Kakek's struggle as well but Kakek ended his struggle with suicidal action so that the surau, as a symbol of holiness, is on the verge of collapse.

After a close reading to the text, students may find all important actants (sender, subject, object, receiver, helper, opponent, and anti-subject) as illustrated below. 


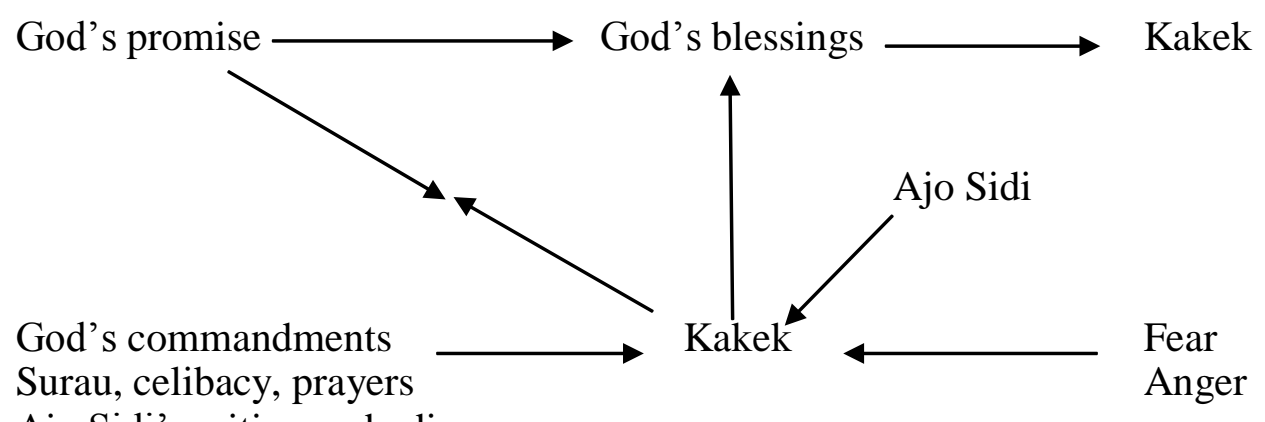

Ajo Sidi's critique, obedience

Because Ajo Sidi likened Kakek to Saleh, another actantial model of Saleh's story can be illustrated as following.

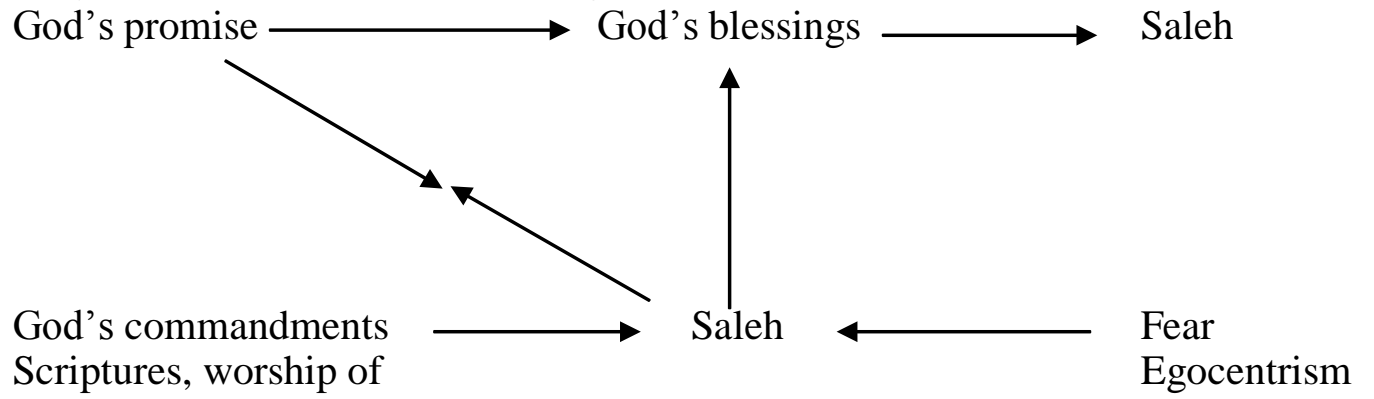

pilgrimage, prayers, obedience

Students may understand from the story that both Kakek and Saleh were bound to God's promise written in the Scripture, which serves as sender in actantial model: "Maka...kami menuntut agar hukuman yang Kaujatuhkan kepada kami ke surga sebagaimana yang Engkau janjikan dalam Kitab-Mu" (Navis, 2010). It is showed here that Saleh and his followers insist God to review His sentence on them and to send them to heaven, instead of hell, as God has promised in His Scriptures.

To meet God's promise (heavenly life), they tried to seize God's blessings but unfortunately they failed: "Tahulah mereka sekarang apa jalan yang diridai Allah di dunia" (Navis, 2010). Here is the object of Saleh's quest, that is, God's blessings, what was really approved by God. They apparently did not know what really pleased God during their earthly life. The same object is pursued by Kakek. "Akan dikutuki-Nya aku kalau selama hidupku aku mengabdi kepada-Nya? Tapi kini aku dikatakan manusia terkutuk" (Navis, 2010). This inner turmoil shows Kakek's concern whether God would curse on him if he dedicated his life to Him and his worries that instead of getting God's blessings, he is called a godforsaken man.

Along with this observation, students should pay attention to values brought by the subject in a form of binary opposition and sorting them according to level of dominance in the text. God's blessings vs God's curse is the most dominant opposition and it serves as the object of Kakek's pursuit. Some other binary oppositions may be said here: piety-impiety, worship-work, egocentric-altruistic. It seems, on the outside, that the opposition between worship and work is so dominant because there is a great portion of discourse during Saleh's trial about 
his work in the earthly life (which is nothing but worship) and even in the end of the story it is clearly mentioned what Ajo Sidi did while other people would join the funeral religious service: Yes, he's going to work. Ajo Sidi brought a value of work more than worship.

It should be noted here that since Ajo Sidi was anti-subject who wanted to criticize Kakek by likening him to Saleh, the name Saleh here was not trivial. The story tells how Ajo Sidi had labelled a leader as frog before finally people called him frog leader. Saleh, then, became appropriate label for Kakek given by Ajo Sidi. It means, piety is the value brought by Kakek in his search for God's blessings and he lived that value by putting worship far ahead of work just as Ajo Sidi described in the story of Saleh.

Since the world of the text is to be found in the intersection between desire axis and communication axis, considering the failure of the subject to get his object, and taking the highest value brought by the subject into consideration, it can be said that the world of the text rolled out by "Robohnya Surau Kami" is the world of a piety that is not legitimized by God's blessings. Students may explain further about this world of the text by posing general questions $(5 \mathrm{~W}+1 \mathrm{H})$ to reveal semantic meanings based on the relationships among actants according to the logics of the story. For instance, God's blessings cannot be found by an observance of God's commandments accompanied by fear. The fear (of hell) corrupts any worship to earn God's promise (opponent-helper-sender). Thus, external religious observance does not guarantee God's blessings. Besides, a piety oriented to a private interest (considering the absolute similarity between subject and receiver) is not legitimized by God's blessings, neither is worship that deprives man of social responsibility.

After elaborating the world of the text, students should make appropriation of it by considering any critique of their own religion and recalling any false belief they hold. In high schools, students will need help of their teacher to discuss some theological issues in accordance with the world of the text. Those issues might be elaborated with Scriptures (For I desired mercy, and not sacrifice; and the knowledge of God more than burnt offerings, Hos 6:6 KJV; Not everyone who says to Me, 'Lord, Lord,' will enter the kingdom of heaven; but he who does the will of My Father who is in heaven, Mat 7:21 NAS), or Tradition that is related with social responsibility (sacrament of reconciliation), or Catholics teachings on nurturing the trafficked mother earth (Laudato Si', for instance) in such a way that the students might open their perspective and thence they deepen their cognitive knowledge, to some extents, about Catholic identity. Appropriation can also be made by triggering creative imaginations whether in reflecting students' experiences or in devising an action or art performance inspired by the world of a piety that is not legitimized by God's blessings.

After the whole process of this interreligious learning, students must reflect on their internal dynamics, that is, their affective, cognitive, and attitudinal dimensions before and after the process. Students should compare their feelings and attitudes toward Moslem world before they were requested to read Moslem short story and after they finished the cognitive process of hermeneutics. They may collect new information about Moslem world, but more important is a new 
insight or awareness of their own Catholic identity. To this point, crosscutting religious education helps students to understand their Catholicity better than before by interpreting Moslem faith expressed in Moslem literatures.

\section{Conclusions}

It can be stated here that crosscutting religious education is an interreligious learning within mono-religious education model. It will certainly not function in religious extremism setting because this model of learning, from the very beginning, assumes moderate attitude. Catholic extremists, for instance, would not read Moslem novels or short stories in order to learn from them. They would read them Crosscutting religious education imposes Catholic students to learn from Moslem or other religious literatures. Therefore, religious literature as other faith's expression is not merely a medium. It is the medium of crosscutting religious education without which mono-religious model remains detached from dialogue with other religious values and attached to the risk of being vulnerable to religious favouritism and communal tensions.

The moderation happens not only in the beginning, but also during the process of hermeneutics. Students cannot impose their opinions or preunderstandings (their own religious prejudices and beliefs) over the text. The objective pole of hermeneutics forces students to do a close reading and to be so faithful to the text that they can find the world of the text which is freed from both their own religious prejudices and the real author's ones. The moderation can also be expected from the result of the study when students realize that other religious text offers values that enrich and broaden their perspectives to deepen their understanding of their own faith. This finding will not allow them to exclude other perspectives to get meanings because, as a matter of fact, those meanings derive from a process involving other religious beliefs. Such a moderation will restrain the tendency of religious extremism.

Without crosscutting religious education, Catholic students may also learn from literature written by a Catholic author and Moslem students from Moslem author. They may involve affective, cognitive, attitudinal, and even volitional dimensions, but other religious beliefs are absent and no moderation can be expected. This interreligious learning within crosscutting religious education gives reason to maintain mono-religious model confidently without any fear of being criticized to be vulnerable to favouritism and communal tensions. They who practice crosscutting religious education respect other religious beliefs since the beginning and learn from them as well in order to nurture broader identity, that is, nationality and humanity.

It certainly demands religious teachers to have an adequate knowledge of both literature and basic theology, besides an openness to a possibility of learning from other religions. Such religious teachers do not necessarily have much knowledge of other religious traditions, though the competence of this area will be very helpful and fruitful, since the aim of crosscutting religious education is appropriation of a particular religion, that is, a better self-understanding. In this case, the role of religious teachers is very important and crosscutting religious 
education might be an appropriate alternative for upgrading their competence of interreligious learning.

\section{References}

Amin, K. (2013). Evaluating religious education. The Jakarta Post, 15 Nov. Retrieved on May 25, 2017, from http://www.thejakartapost.com/news/2013/11/15/evaluating-religiouseducation.html

Berling, J. (2004). Understanding other religious worlds: A guide for interreligious education. Maryknoll: Orbis Books.

Chang, R. (Ed). (1997). Incommensurability, incomparability, and practical reason. Cambridge, MA: Harvard University Press.

Fisoni, V. (2005). From the encounter to the dialogue. A Parte Rei, 40. Retrieved on May 20, 2017, from http://serbal.pntic.mec.es/ cmunoz11/fisogni40.pdf

Gallagher, M. P. (2003). Clashing symbols: An introduction to faith and culture. London: Darton, Longman \& Todd.

Grad, I. (2014). Religion, advertising, and production of meaning. Journal for the Study of Religions and Ideologies, 13(38), 137-154.

Haryatmoko. (2016). Membongkar rezim kepastian: Pemikiran kritis poststrukturalis. Yogyakarta: Kanisius.

Jackson, R. (2016). Religious education in European organisations, professional associations and research groups. In Jenny Berglund et al. (Eds.) Religious Education in a Global-Local World. Cham: Springer International Publishing AG.

Lijphart, A. (1977). Democracy in plural societies: A comparative exploration. New Haven, CT: Yale University Press.

Navis, A.A. (2010). Robohnya surau kami. Jakarta: Gramedia Pustaka Utama.

Pollefeyt, D. (Ed.). (2007). Interreligious learning. Leuven: Leuven University Press.

Powell, A. (1990). What is narrative criticism? Minneapolis: Fortress Press.

Ricoeur, P. (1976). Interpretation theory: Discourse and the surplus of meaning. Fort Worth, TX: Texas Christian University Press.

Ricoeur, P. (1991). From text to action: Essays in hermeneutics II. Evanston: North Western University Press.

Simms, K. (2003). Paul Ricoeur. New York: Routledge.

Sterkens, C. (2001). Interreligious learning: The problem of interreligious dialogue in primary education. Leiden: Brill.

Ullah, K. (2015). Why do people become Islamist extremists? YouTube, uploaded by PragerU, 15 June, https://www.youtube.com/watch?v=-IchGuL501U.

Ward, G. (2005). Cultural transformation and religious practice. Cambridge: Cambridge University Press.

Yusuf, M. (2016). Religious education in Indonesia: An empirical study of religious education model in Islamic, Christian and Hindu affiliated schools. Berlin: LIT Verlag. 
Yusuf, M. \& Sterkens, C. (2015). Analyzing the state's laws on religious education in post-new order Indonesia. Al-Jāmi'ah: Journal of Islamic Studies, 53(1), 105-130.

Ziebertz, H. (1993). Religious pluralism and religious education. Journal of Empirical Theology, 6(2), 82-99. 